\title{
The Role of Family in the Construction of Traditions among Second-Generation Chinese Immigrants in Hungary
}

\section{Introduction}

The family is the most important social construct in the immigrant's life. It plays a truly complex role: acts as a link between the host and home society; conserves the traditional values; also introduces new cultural forms; a genuine environment where ideas and values can clash, and generations are able to negotiate. To successfully take up all these roles, the boundaries, the structure and the rules of the family have to be flexible and adaptable. The immigrant family is a rather interchangeable creation which has to reevaluate its standards frequently according to the requirements of the host society and the needs of the family members. ${ }^{1}$ Culture plays a central role in this reevaluation process, as well as in the negotiation between generations where the outcome is based on the size of the cultural distance between these factors. ${ }^{2}$

Chinese immigrant families in Hungary also organize themselves according to this formula. In this article we focus on families constructed by two generations in which the second- generation has grown up in Hungary. In our cases parents arrived in the country 20-30 years ago taking up with the challenges caused by migration. They are the old members of the Hungarian Chinese diaspora, calling themselves lao yimin 老移民, 'old migrants'. It is known from studies conducted on this subgroup that many among them came to make their fortune in Hungary; they are the big survivors, big innovators, people who could adapt and endure even at times when many of their peers couldn't. Usually their youth were spent with hard work and learning in a new environment, and in the

\footnotetext{
* MTA-ELTE-SZTE Silk Road Research Group

${ }^{1}$ Foner 1997: 961.

${ }^{2}$ Foner-Dreby 2011: 547.
} 
process of acculturation they were often forced to revisit and reevaluate their norms and traditions. ${ }^{3}$ The twenties of the lao yimin were spent differently from the twenties of their children. The parents socialized themselves in times and in cultures which required their own set of skills not necessarily regarded useful by their children anymore.

The children of the first-generation immigrants who grew up in a multicultural setting have their own challenges to deal with. They built up their identity from elements learned from their parents and picked up from the host society. This identity shows a high degree of complexity which goes beyond the definition of biculturalism. Even though they value their parents' traditions, they are the ones who challenge them. ${ }^{4}$ Given this situation in the immigrant family, the dialog between these two generations, based on their different understanding on norms and values, is often complicated.

As we will show in the next sections, in many cases Chinese immigrant families try to balance between traditional norms and learned behaviours. This tiptoeing often results in conflict and negotiation between generations and can produce new traditions and hybrid cultural elements.

\section{The case of Hungarian Chinese second-generation immigrants: methodology and terminology}

To gain better understanding on what role the family plays in the life of the second-generation Chinese immigrants, we conducted 20 semi-structured anonymous interviews with young adults aged 18 to 33 . The interviews took place in Budapest, Hungary in the interval of 5 month from October 2019 to February 2020. Each interview took 60 to 90 minutes, was conducted in Chinese and Hungarian and with the consent of the interviewees they were recorded. After the transcription we organized and analysed the content of the material and elicited the meaning from it to draw our conclusions. Out of the 20 interviewees: 12 were born and lived in Hungary with two first-generation Chinese immigrant parents; 5 were born in China, arrived at Hungary before their adolescent years and lived in the country with two first-generation Chinese immigrant parents; 3 were born and lived in Hungary and had a mixed heritage with one Chinese and one Hungarian parent. According to the definition of the European Commission and Asher the first group could be regarded as 'second generation', 5 the second

${ }^{3}$ Nyíri 2013: 3861, Guo 2010: 123, Várhalmi 2010a: 173, Huang - Gove 2012: 10, Suárez-Orozco - Suárez-Orozco 2015: 128, Sebestyén - Fülöp 2014: 145.

${ }^{4}$ Suárez-Orozco - Suárez-Orozco 2015: 133, Foner - Dreby 2011: 549.

5 According to the definition of the European Commission. Our experiences tell us that Chi- 
group as ' $1.5^{\text {th }}$ generation' and the members of third group as 'individuals with mixed background'. ${ }^{7}$ However, in this article we will use the title 'second generation' as an umbrella term for the sake of simplicity, and also because we consider these young people as the members of the second generation in their respective families.

\section{Changes of traditions in the Chinese immigrant family}

In this section we discuss the special situation of traditions in the Chinese immigrant family in Hungary, paying closer attention to the differences between the two generations.

\subsection{Flexibility of the traditions}

Previously we mentioned that the immigrant family setting provides an exciting environment to traditional norms and values to clash with new ones. Usually in this disposition the members of the first generation are more attached to the traditions brought over from the home society and the members of the second generation tend to represent the new norms. ${ }^{8}$ However, oversimplifying the situation by making a division like first generation - traditionists, second generation-reformers would not be correct.

Tradition is a complex phenomenon and hard to define. Based on the literal meaning of 'handed over', it is often regarded as a collection of cultural elements and features found worthy to preserve and pass on by someone ${ }^{9}$ which, as a result, have survived with the process of transmission from one generation or individual to the other.

nese immigrant children born in Hungary were often sent back to China in their toddler years. Usually raised by the maternal grandparents, many of them even started primary school there. It seems it was a common phenomenon among first-generation early migrants who arrived at Hungary to open their own businesses which took most of their time. Usually when the children reached school age they were brought back to Hungary, where they were raised with the help of a Hungarian nanny. Even though they were born in Hungary, they needed to relearn the language and culture which were alien for them. Given their special situation it is challenging to label their group according to existing definitions.

${ }^{6}$ According to the definition of Curt Asher (Asher 2011: 44).

${ }^{7}$ According to the definition of the European Commission.

${ }^{8}$ Foner - Dreby 2011: 547.

${ }^{9}$ Graburn 2001: 6. 
However, if we look closer, we can discover the limitations of this definition. Tradition is a sort of cultural reproduction which results in the replication of an action someone already had done before. This process incorporates two parts: repetition of something old which had already existed before and the construction of something new. That is why we cannot consider tradition to be static and unchangeable; in reality it is the creation of an actual person in a given time influenced by actual circumstances. Flexibility is in the nature of tradition, since it has to withstand the challenges of different times and it needs to be adaptable. As Oring points out, tradition comes from the past but constantly mutates; it has to be modified and transformed or else it disappears. The exciting question is how long a tradition can maintain itself, and when it changes to a degree that it ceases to be a tradition and evolve into something new. We can even go to the extent to say that tradition is 'change', something 'new' and 'unique.' 10

When we focus on immigrant cultures, we also recognize how tradition is tied to uncertainty. These traditions must survive in a different cultural setting of the host society. Due to the need to fit in this new cultural environment, they are often overridden, retranslated and many times they only survive as an element of a new tradition. Traditions are rather individualistic, they are strongly dependent on the person who recreates them, and in the life of the immigrant they are often romanticised to the degree when they become more significant than they used to be. ${ }^{11}$

If we accept this thread, we understand the complex phenomena attached to the traditions of Hungarian Chinese immigrant families. According to the findings of our research, a certain kind of reevaluation and merging process can be discovered in regard: the size of the family; the dynamics within its boundaries; the way how the generations negotiate the institution of filial piety, celebrate holidays and create their own language.

\subsection{Challenging the brought over traditions: everlasting Confucianism and the imprinted xiao}

Even though times are changing and China with its large overseas population is going through a huge economic, social and cultural transformation, regardless of their location, the dynamics and the structure of Chinese families are still influenced by Confucian traditions. This inherited collection of ethics, moral rules and teachings still constitute the backbone of Chinese culture, and they can

\footnotetext{
10 Oring 2013: 22-25.

11 Foner 1997: 963.
} 
be identified even in the most insignificant decisions of a person. ${ }^{12}$ Confucian ethics underline the foremost importance of the family. Shaped by experiences produced by a long history, and due to the lack of trust in other social constructs, the family earned the privilege to become the most important social unit in Chinese people's life.

The role of the family is so significant that the individual's sense of self is strongly attached to it. This culture underlines the belief that the person should strive in behalf of the whole family. ${ }^{13}$

Family is not only important for the first-generation Chinese immigrants in Hungary. According to our findings, it maintains its central role in the life of the second-generation Chinese immigrants as well. Many of the interviewees reported strong attachment to their parents and siblings.

"Maybe it is a cliché... but they say how important family is in Chinese culture. And if I think more, I have to realize how close I am to my parents, especially to my mother. I love to hug them. I can see among my Hungarian friends that these two generations are more far apart, and the gap is bigger between them. And yes, there is this sense in Chinese culture that even if you are close to others you should be open to your family members. Your family always will be your family. And I think it is a really important thing."

Chinese migrants are usually considered to be the typical representatives of network migration. The information provided by the people of their networks help them choose the best migration strategy and their success in the new environment is also influenced by the capability of profiting from those networks. This type of intense networking is in accordance with the attitudes of East Asian cultures. There are theories stating that the rapid economic growth in the region was strongly reliant on network capitalism. ${ }^{14}$ In the Hungarian environment Chinese communities also build up their layered extended networks and they tend to include many relatives both from the home country and the host society. These relatives are instrumental to the economic growth and they also provide emotional support. ${ }^{15}$ Having friends and relatives in the host society can give a lot of comfort, especially during the first years in the new country. They represent the familiar in an unfamiliar environment. They speak the same language, they like the same type of food and they have the same cultural traditions.

\footnotetext{
${ }^{12}$ Huang-Gove 2012: 10.

13 Fukuyama 1996a: 85-86, Huang - Gove 2012: 10.

14 Putman 1993: 38.

15 Várhalmi 2010b: 178.
} 
We found that even though their extended network contains a lot of relatives, the immigrant family is limited in its size and tend be rather small. The members of the second generation have a strong sense of the nuclear family only including parents and siblings, even if in many cases other family members from the parents' side had also migrated with their children. It is not clear why the nuclear family is so exclusive, but it seems likely that the trust and the system of dependency play key roles in it. Somehow in the process of migration and integration this nuclear family was born, and its member have the highest degree of trust in each other. ${ }^{16}$ As the result of the language barrier and different cultural settings, the children of the immigrant family are strongly dependent on the parents' view of the host environment, and later, the parents will rely on the help of their more integrated children. They tend to think of themselves as a unit who imagine their future together, more or less tied to each other. ${ }^{17}$

The way family members trust each other can be explained by the still existing notion of filial piety. One of the central virtues of the Confucianism, xiao 孝 obliges the children to respect and support their parents, elders and ancestors throughout their life. Xiao traditionally leads to the construction of a tight family hierarchy in which there is no place for challenging the parental authority. ${ }^{18}$ If the children do so, they often do it with unease bearing the consequences of the loss of their face (mianzi 面子), their righteousness and pride, which will be reflected in their social status. Filial piety withstood the challenges of the changing times and was perfected to the extent that even if family members can't trust each other, they can still trust the system of xiao. ${ }^{19}$

Our interviews showed that respecting the parents and elderlies also comes naturally to the second-generation Chinese immigrants. They honestly want to give respect to the parents and help them when they need help. They value the institution of xiao and they feel it is missing from Hungarian culture.

"Hungarians could learn about respecting the elderly. I see that many Hungarian young people won't respect their parents and the elderly. They treat them like lepers."

"There is something in China... called xiao, the respect for the elderly. I believe that is something right to do. When the kid grows up and leaves the house of the

16 Foner - Dreby 2011: 548.

17 The formation of extended families faces challenges not only overseas but in the Chinese homeland as well, as it is restricted by the economic growth and the limited space provided by the cities. Yang - Scott 2014: 2.

18 Fukuyama 1996b: 85, Lieber et al. 2004: 325.

${ }^{19}$ Huang - Gove 2012: 10. 
parents, it should not be like... [he] leaves and never looks back, and that is all. The parents also need to be taken care of. If they brought us up, we should help them when they get old, or something like that."

We also found that in the case of the second generation, xiao can be traced down to the relation to the ancestral line. Even though the members of the second generation regard the family as a nuclear unit, there is still a sense of a large lineage they tend to tie themselves to. They feel kinship to their ancestors, and regard themselves as members of a bigger bloodline which originates in China. Many of them respect and value this heritage and express the feeling of loss when thinking of breaking that lineage.

"It is so important to teach Chinese culture for my future kids. I know that from my mother's side the family tree is huge in China, and if I marry a local [Hungarian] man, this branch will die out with me, and I don't want that. I even had this crazy idea that I adopt a baby from China who will keep in touch with the family there."

As it can be seen the question is not whether there is xiao or not, the question is the degree or amount of xiao given to the parents and whether the parents are satisfied with it. The culture of xiao is so deeply rooted in the first generation's identity that even parents who seemingly disowned their Chineseness were still strongly demanding it from their children.

The conflict within the immigrant family rises when the members of the first generation feel they don't receive the respect they deserve from the members of the later generations. This conflict is even stronger when the member of the second generation is more integrated into the host society and feels distanced from the culture of the parents and at the same time the parent strongly ties him- or herself to the "traditional" values. In these cases, the parents' wishes and rules are felt unreasonable and over-restricting for the children. ${ }^{20}$

"I know I'm a rebel. And my father doesn't take this well... that I won't obey his majesty. But sadly, I have European education."

However, as we mentioned before, the life of the immigrant family is based on constant negotiations. Cultural, social change like migration usually weakens the position of the brought traditions. In order to survive in a new social and cultural environment, the family has to adapt, and as a reason of this adaptation,

${ }^{20}$ Foner - Dreby 2011: 547. 
the parents often reevaluate their set of values and traditions. ${ }^{21}$ According to our interviews, the Chinese immigrant parents don't exercise strict parental control in every segment of their children's life and they give them bigger freedom than they would do in their home country. At the same time, children also have their own take on filial piety. They don't blindly obey their parents, dare to question them, and in some cases they break the rules laid down by the first generation.

“[About taking the parents' advice]: Luckily my mother is pretty open-minded, she accepts my opinion. Of course, I won't listen to her all the time. If we have a different opinion, I won't listen to her."

However, there are segments in the second-generation immigrant's life which receive particular attention from the parents; education, dating and marriage, and language skills. Since the parents exercise the greatest control over these segments, these are the focal points where most of the negotiations may take place.

\subsection{Education}

Confucian traditions also have a strong influence in the evolution of attitude towards education. Education has a central role in Chinese culture and in children's upbringing. Among those new wave Hungarian Chinese immigrants who arrived in the country recently, many migrated to provide a better education for their children. This deep-rooted emphasis on education relies on the classical Confucian belief that educated people will get the top places in the hierarchy. Better education means that the person has better chance to obtain a decent job, which can give both financial safety and mianzi for the whole family. Chinese parents in the traditional sense are the figures of authority, and they have the responsibility to bring the best out of their children. ${ }^{22}$ In this bilateral relation children feel the obligation to be respectful and maintain good academic achievement and the parents also feel the obligation to overview the children's education. The failure of the children would mean the failure of the parents. ${ }^{23}$

Our findings show that the children of immigrant parents certainly have a lot of challenges to deal with. They are going through important steps of their lifechildhood, early adolescent years, etc.- - sometimes in the middle of the migra-

\footnotetext{
${ }^{21}$ Huang - Gove 2012: 10, Lieber et al. 2004: 327-328.

${ }^{22}$ Huang - Gove 2012: 10, Lieber et al. 2004: 326, Borsfay - Nguyen 2018: 11.

${ }^{23}$ Huang - Gove 2012: 13.
} 
tion process. Those second-generation immigrants who actually had to move back and forth between China and Hungary needed to be extremely adaptable.

"[About the hardship when she moved back to Hungary to enrol in primary school]: Yeah, back then I had no idea what was going on, where I was, who I was and what I had to do.”

They had to find their way in a new culture, and socialize themselves with peers they had trouble to communicate with.

"Here I had to enrol in primary school, but back then I didn't really know Hungarian... I had to enrol into $6^{\text {th }}$ grade... My primary school years were awful. I constantly needed to take extra classes, I thought I wouldn't survive..."

The conflict rises when parents don't understand the emotional hardship their children are going through, and they keep raising their expectations. In many cases parents expressed their disappointment when their children didn't do well academically after they had enrolled into the Hungarian education system.

\footnotetext{
"At the first year of high school I got B-s and C-s mostly, and a couple of D-s. And I learned everything by myself. It was not like primary school anymore. It was really hard for me to learn those subjects in Hungarian. And when I showed my grades to my father, he asked me why I couldn't do better. I got so upset and pissed. After I showed those grades to my private teacher she said that she was proud of me, because I achieved everything by myself, and she also said that I shouldn't give a damn about what my father said, since he had no idea what it was like."
}

The average Chinese immigrant parent feels the obligation to provide all the necessities for their children to do well academically. Thanks to their widespread networks they know which institutions are the best for their children, and if they are dissatisfied with the results, they are not afraid to change schools quite frequently. Besides the compulsory education, parents tend to take their children to extracurricular courses and weekend schools. Since they compare themselves to their Hungarian peers, the children find these extra activities overwhelming and unfair.

Education plays a central role not just in the children's but also the whole immigrant family's life. In the case of the lao yimin we should also consider how migration reinforced this attitude. Many of hard-working first-generation migrants had to do hard labour to make ends meet and to provide a better future 
for their families. They want their children to enroll in a good university to procure a better life than they did. ${ }^{24}$ With the children's success the parents also feel fulfilled and they take pride in the achievement.

“... Chinese parents are not proud of what they have been through [during the first years of their migration], but they are proud of their children if they can go to university and earn a lot of money. They won't talk much about what they went through in '96, but they will talk about us [children], what we achieved and what they could provide for us."

The school environment is a really important part of the immigrant children's lives. This is where they must face the host society's environment and make connections on their own, outside of the immigrant family, on a daily basis. This is where the children have to deal with the constant assimilating influence coming from their peers and teachers. ${ }^{25}$

"Well, at home I learned the Chinese costumes and at the school I learned the Hungarian ones. There was a really Chinese situation in the primary school. I was eating soup and there was some left in the bottom of the bowl, and I picked the bowl up and started to drink the soup out of it. And the teacher showed up, and said to me: Darling, don't do that! You have to put down your bowl, and use your spoon to eat the soup, nice and slowly. I still keep this habit, and at home my mother often asks me what my deal is, why I'm eating so quietly."

\subsection{Marriage and dating}

The other important field which enjoys overwhelming parental focus is the field of marriage and the choice of the future spouse. In the life of the immigrant family forging kinship ties like marriages within the community can help to succeed in the new environment. ${ }^{26}$ Our findings showed that in the case of Chinese immigrants the parents of the second generation often wish their children to marry someone who is Chinese. They have the desire to communicate fluently with their in-laws and some of them are afraid that marrying someone from the host society will make their children's life harder. In their eyes, Hungarian in-laws speak a different language, have a different culture, and locals have a tendency to divorce easily. Even though they would create a stronger link between the

\footnotetext{
${ }^{24}$ Suárez-Orozco - Suárez-Orozco 2015: 132, Guo 2010: 132.

25 Kibria 1993: 146.

${ }^{26}$ Foner 1997: 965.
} 
family and the host society, it is still too much trouble for a little benefit. This determination to keep family unity and have the same understanding on culture and language sometimes goes to the extent that some parents don't just want a Chinese partner, they want a Chinese partner from same province where they came from.

"In my family they say: 'It is ok that you have a Chinese girlfriend, but it is not enough. We want you to have someone from the same province which we are from.' ... I think they are like this because China is huge, and the culture and costumes, the language is different everywhere."

This wish of the parents is usually understood by the members of the second generation, and most of them find it reasonable. Confrontation starts, when the children feel the parents overstepped their boundaries and practice too much control over their personal life. This also occurs when parents act like traditional keepers and children already socialized themselves in a different cultural environment. In this case the bigger the cultural difference between the host and home society, the harder the negotiation is between the two generations. ${ }^{27}$

\begin{abstract}
"They [the parents] already got used to the life here [in Hungary], but they can't get used to the culture. Since my father is really traditionalist, he thinks in a more conservative way... When I wanted to make friends with boys, he didn't let me.... Until today I had a couple of boyfriends. The first, when I was 16. One day he walked me home, and for my surprise my father appeared and told me to go home, and he would invite my boyfriend for a cup of coffee. I went home, and I was in shock. What else could I have done? I went home like a robot."
\end{abstract}

\title{
3.5. Language
}

Language has a special role in the immigrant family's life. Besides being the most widely used instrument for communication and self-expression, it is a visible marker of integration and an important medium for keeping traditions. Depending on the capability of learning a new language and keeping the old one, this multipurpose tool contributes to the survival of the immigrant family in the new environment and attaches them to their familiar culture. ${ }^{28}$ It is a channel used during the negotiation process, and it itself can be the subject of those negotiations.

\footnotetext{
${ }^{27}$ Foner - Dreby 2011: 547.

${ }^{28}$ Gelmana - Roberts 2014: 7901, Esser 2006: 1.
} 
The children of the first-generation immigrants have the chance to get familiar with at least two languages during their childhood. They are often titled as bilinguals, even though bilingualism in its pure form is a non-existing phenomenon. Depending on the level of their integration, they are dominant users of one of these languages. ${ }^{29}$

We found that in the second generation's life usually home is the space where they use Chinese dominantly. However, depending on where the family originates from and whether there are more children in the family, the situations can differ widely. If the parents came from a province where they use a local dialect, they tend to use that dialect at home. If the children don't have a grip on that dialect, the communication is mixed, parents using the dialect and the children answering them in Mandarin. Conflict arises when the parents have expectations for their children to speak the dialect and the children aren't able to do so and experience constant sense of failure.

"I couldn't learn the local dialect. There's something inside me, which is blocking it. This is a spoken language, it doesn't have a written from... It often frustrates me. My father often asks me: Why haven't you learned the dialect already?! And I tell him, damn it, give me a book and I learn it."

The dialect in the immigrant family setting symbolizes the emotional attachment to the parents' home, and sometimes knowing it is the only way to communicate with the grandparents.

The attitude towards languages is fueled by the parents' high expectations pressuring the children to be fluent in as many languages as they can. By their adolescent years, children act as the family's agents being able to translate using Hungarian, Mandarin and sometimes a local dialect. Parents have a clear idea on the value of these languages. Even though learning Hungarian is a time-consuming investment, it's still important for the well-being of the family in the host society. With the economic development of China and the increasing number of Chinese tourists in Hungary, parents consider Mandarin Chinese as a valuable asset, therefore it is expected to be practiced by the children. Besides these, the parents want their children to speak the local dialect of their homeland and learn at least one more language, most often English or German, to be able to go abroad. Many of the children are multilingual, capable of switching between languages without any problem, but this skill often comes with the feeling that they can't use any of these languages perfectly.

${ }^{29}$ Nesteruk 2010: 272. 
Family is the environment for the creative process where siblings create their own method of communication. Given their multilingual situation they often mix the words and grammar structures of the languages they use. According to their description most of the time it is not a conscious choice, mixing the languages happens for the sake of maintaining a fluent communication.

"When I talk to my brother, we use all kinds of languages. We mix them a lot. We often start to talk about something like the weather, and when I have trouble recalling a word in the given language, I will switch to another one, and he will understand it. We can switch without any trouble. We talk two sentences in Chinese and two sentences in Hungarian."

Mixing the languages can also give an opportunity for the siblings to create their own domain within the family. By profiting from their multilingual situation, they can invent a hybrid language which is used only between them excluding the parents.

\begin{abstract}
"With my sister sometimes we... how should I say... use a special language, what we call Chingarian [Chinese and Hungarian, 'kigyar' in Hungarian]. We invented this. For example, if there is some sort of housework we need to do, we will use the Chinese word xiwan 洗完 and add a Hungarian suffix to it. And we will say: Will you go to xi wan? [in Hungarian: xiwanozni]. So, we do this sort of stuff."
\end{abstract}

\title{
3.6. Dependency vs. Independency
}

According to previous findings the close control practiced by the parents can make the children feel troubled to find a balance between dependency and independency. ${ }^{30}$ In the case of the second-generation Chinese immigrants in Hungary we found that parents oversee the life of their children even well into their twenties, and practice control over it at some degree.

"I think in the eyes of the Chinese parents their children always will be children. So they feel they have to take care of them. For example, they say that I should not meddle in their business and I should shut up, since I'm just a kid and I don't know anything. But I'm already twenty years old... It hurts of course, but then I shut up [laughing]."

${ }^{30}$ Huang - Gove 2012: 13. 
Immigrant children, however, speak the host society's language better than their parents do, and can act as cultural brokers; translating, interpreting and managing official matters for the whole family. ${ }^{31}$ This makes parents dependent on their children to some extent and give the children some independence.

We also found that on the one hand parents struggle to give enough authority to their children to practice, in the other hand the children must take over more responsibility much earlier than their Hungarian peers do.

"Why is it important to my parents whether I speak good Hungarian or not? One word: translator machine, I'm a translator machine for them [laughing]."

"When I was fourteen, I needed to accompany my father to the court, because they didn't find an interpreter. And my father asked the judge whether they let me translate for him or not. Since they couldn't figure out another solution, they said 'ok'. And the judge asked my father if I had any problem understanding Hungarian, and my father's response was that I could speak fluent Hungarian, I only had a problem with Chinese. And I sat down in the courtroom... and that was something. It was a lot to take in. And the judge was talking to me like I was mentally challenged, it was really funny."

\subsection{Creation of hybrid traditions}

As we saw before, the immigrant family is a very dynamic institution. Parents and their children have to find a common ground for their different values and norms; many beliefs and cultural patterns undergo change, while others persist and stay. Within this creating process, sometimes something new occurs which reflects the elements of both the home and the host society's traditions, but in the same time it is also different from those. ${ }^{32}$ This creative process can be discovered in the changing of holiday traditions.

According to our findings, in the case of holidays what is kept and what is abandoned strongly relies on convenience and availability. The Chinese holidays don't overlap in time with the Hungarian ones. Their biggest festival is the Chinese Spring Festival, which is a huge family celebration, lasts for a week and changes its time every year according to the lunisolar calendar. Although this holiday is kept by the Chinese immigrant family, they are not able to celebrate it completely in the traditional way. Usually they reduce it to one night when the nuclear family and a couple of their friends and other relatives get together to

${ }^{31}$ Foner - Dreby 2011: 548.

32 Foner 1997: 965-966. 
eat, watch the same Chinese TV program as the one broadcasted in China, and give hong bao 红包, a sort of red envelop filled with money, to their children. As it is the case with many festivals, food enjoys a central role in the celebration. Even though many of the ingredients can be found in Chinese markets, most of the immigrants still complain how the variety of fruits and vegetables is much smaller in Hungary than in China. Sometimes they have to be innovative and use Hungarian ingredients to create traditional Chinese dishes.

Holidays strictly reliant on special places can't survive in Hungary. A good example for this is the Tomb Sweeping Festival (Qingmingjie 清明节), when the whole family is supposed to visit the ancestral tombs, clean them, leave food offerings there, burn joss ticks and joss money. Since the ancestors of these Chinese families are buried in China, even though they find it important to commemorate them, they are not able to celebrate it as they would do in their home country.

The task of introducing new cultural elements often rests on the shoulders of the second generation who combine aspects of their parents' culture and the culture of the host society. ${ }^{33} \mathrm{We}$ saw that in many cases children are the indicators of picking up new holiday traditions. Typical case is Christmas which is learned by the members of the second generation at school, from their peers, Hungarian nanny or private tutor.

"I celebrate Christmas. I told him [to his father], 'If you celebrate Spring Festival, then I celebrate Christmas.' I told him, the presents are not important, the important is that we get together, spend some time with each other and wish Merry Christmas. That's it. And he replied: 'Ok'."

There is a sort of hybridity in these holidays and they are often celebrated in a modified way. In many cases only those elements are kept that can also be understood and valued from the parents' cultural point of view. In our cases Christmas was celebrated by the family with missing traditional elements. Sometimes they didn't buy Christmas trees or instead of presents they gave hong bao 红包 to the children. However, they always kept the element of gathering and eating together even though the celebrational food was strongly influenced by Chinese taste.

"[About what he misses from their Christmas celebration] I miss the kind of habit that you take time and think about what the other likes, and you buy the presents based on this. This is missing from home. Ok, my parents give me money, and

${ }^{33}$ Foner - Dreby 2011: 549. 
I also give them smaller presents, but this is not really typical in Asian cultures. Chinese people are really family-oriented, but still it is missing from their culture that they give thoughtful presents. This is really strange for me, and I think it is a really important thing."

As we mentioned, traditions in the immigrant family are quite fluid and often exist only temporally. The importance of celebrating Christmas often faded away with the children growing up.

\section{Conclusion}

As we have seen, in the life of second-generation immigrants family enjoys a central role, providing a rather complex environment for ideas, norms and values to meet each other. In this settings there are traditions which withstand the social and cultural changes caused by migration and still influence the dynamics within the family. Elements of Confucian personal ethics and the practice of filial piety can be discovered in the different segments of the immigrant's life. In harmony with these traditions, the importance of the family, the ancestral heritage and the respect given to parents is still highly valued by the members of the second generation.

As the traditions and norms brought over by the members of the first generation have to survive in the host society's new cultural environment, they are often revisited and modified according to the requirements of the new situation. Recognizing the need of being adaptable, parents tend to be more flexible regarding the upbringing of their children, and able to give them more space to express their own take on the traditional norms. However, there are fields - such as education, dating and marriage, and language knowledge - which are highly valued by the parents and are the subject of more negotiations between the generations. Conflict rises in cases when children feel the parent's expectations are too high, and their interference is inappropriate.

As brought over and newly picked up traditions meet in the environment of the family, they often undergo changes. One of the most visible subjects for these dynamics are the holiday traditions. The family is influenced by the host society and tend to personalize the holiday traditions according to convenience and availability. Most of the major Chinese festivals are still kept in Hungary, even though they are frequently modified to fit the new circumstances. There are holiday traditions which are newly learned in the host society and often introduced by the members of the second generation. Most typical case is Christmas 
which is celebrated although it is modified according to the understanding of the immigrant family.

It has to be kept in mind that in this article we only studied second-generation immigrants whose parents arrived in Hungary 20 to 30 years ago. Because of the complexity of the Chinese diaspora we were able to cover only one segment of the researched subject. The findings can depend on many factors such as time and purpose of migration, age of the parents and their children, home province, educational background, etc., which would call for more researches conducted on the topic. Our goal was to add new insights to already existing literature, and to show the complexity of the dynamics between the Chinese immigrant family and traditions.

\section{References}

Asher, Curt 2011. "The progressive past: How History Can Help Us Serve Generation 1.5." Reference \& User Services Quarterly 51.1: 43-48. https://doi.org/10.5860/rusq.51n1.43

Borsfay Krisztina - Nguyen Luu Lan Anh 2018. "Megküzdés a migránslét kihívásaival. Magyarországi kínai gyerekek akkulturációs tapasztalatainak feltérképezése" [Coping with the challenges of being a migrant. Exploring acculturation experiences of Chinese children living in Hungary]. Alkalmazott Pszichológia 2018.4: 7-33.

Esser, Hartmut 2006. "Migration, Language and Integration." AKI Research Review 4.

European Commission n. d. "Migration and Home Affaires." 13.04.2020. URL: https://ec.europa.eu/home-affairs/what-we-do/networks/european_migration_network/glossary_search/ second-generation-migrant_en

Foner, Nancy 1997. "The Immigrant Family: Cultural Legacies and Cultural Changes." The International Migration Review 31.4: 961-974. https://doi.org/10.1177/019791839703100407

Foner, Nancy - Dreby, Joanna 2011. "Relations Between the Generations in Immigrant Families." Annual Review of Sociology 2011.37: 545-567. https://doi.org/10.1146/annurev-soc-081309-150030

Fukuyama, Francis 1996. Trust: The Social Virtues and the Creation of Prosperity. New York: Free Press.

Gelmana, Susan A. - Roberts, Steven O. 2017. "How language shapes the cultural inheritance of categories." PNAS 114.30: 7900-7907. https://doi.org/10.1073/pnas.1621073114

Graburn, Nelson H. H. 2001. "What is Tradition?" Museum Anthropology 24.2/3: 6-11. https:// doi.org/10.1525/mua.2000.24.2-3.6

Guo Xiaojing 2010. "Beilleszkedtek-e a magyarországi kínaiak?” [Are the Hungarian Chinese integrated in Hungary?] Távol-keleti Tanulmányok 2010.1: 123-133.

Huang, Grace Hui-Chen - Gove, Mary 2012. "Confucianism and Chinese Families: Values and Practices in Education." International Journal of Humanities and Social Science 2.3: 10-14.

Kibria, Nazli 1993. Family Tightrope: The Changing Lives of Vietnamese Americans. Princeton University Press.

Lieber, Eli et al. 2004. "Filial Piety, Modernization, and the Challenges of Raising Children for Chinese Immigrants: Quantitative and Qualitative Evidence.” Ethos 32.3: 324-347. https:// doi.org/10.1525/eth.2004.32.3.324 
Nesteruk, Olena 2010. "Heritage language maintenance and loss among the children of Eastern European immigrants in the USA." Journal of Multilingual and Multicultural Development 31.3: 271-286. https://doi.org/10.1080/01434630903582722

Nyíri Pál 2003. "Új kisebbség Magyarországon: a kínaiak” [New minority in Hungary: the Chinese]. Barátság 10.2: 3865-3871.

Oring, Elliot 2013. "Thinking through Tradition.” In: Blank, Trevor J. - Howard, Robert G. (eds.) Tradition in the 21 $1^{\text {st }}$ century: Locating the role of the past in the present. Boulder, Colorado: University Press of Colorado, 22-48. https://doi.org/10.7330/9780874218992.c01

Putnam, Robert 1993. "The Prosperous Community: Social Capital and Public Life.” The American Prospect 1993.13: 35-42.

Sebestyén Nóra - Fülöp Márta 2014. “A versengés, győzelem és vesztés szubjektív jelentése magyar, kínai és Magyarországon tanuló kínai diákok körében” [Subjective meanings of competition, winning and losing among Hungarian, Chinese and Chinese immigrant students living in Hungary]. Magyar Pszichológiai Szemle 70.1/9: 143-158. https://doi. org/10.1556/0016.2015.70.1.9

Suárez-Orozco, Carola - Suárez-Orozco, Marcelo M. 2015. "Structuring Opportunity for Immigration Origin Children." In: Antonio M. Battro - Ingo Potrykus - Marcelo Sánchez Sorondo (eds.) Bread and Brain, Education and Poverty. Proceedings of the Working Group, 4-6 November 2013. [Scripta Varia 125.] Vatican City: Libreria Editrice Vaticana, 127-164.

Várhalmi, Zoltán 2010a. "A budapesti kínai és vietnámi gazdasági klaszterek néhány jellegzetessége" [Some Characteristics of Chinese and Vietnamese Economic Clusters]. In: Hárs Ágnes - Tóth Judit (eds.) Változó migráció - változó környezet [Changing Migration - Changing Context]. Budapest: MTA Etnikai-nemzeti Kisebbségkutató Intézete, 173-189.

Várhalmi, Zoltán 2010b (2011). "Magyarországi migánsok kapcsolathálójának típusai, jellegzetességei" [Types and characteristics of the migrant networks in Hungary]. In: Örkény Antal - Székelyi Mária (eds.) Az idegen Magyarország. Bevándorlók társadalmi integrációja [The Foreign Hungary. The Social Integration of Immigrants]. Budapest: MTA Etnikai-nemzeti Kisebbségkutató Intézete - ELTE Eötvös Kiadó, 169-187.

Yang Hu - Scott, Jacqueline 2014. "Family and gender values in China: Generational, Geographic, and Gender Differences.” Journal of Family Issues 39.9: 1-27. 